\title{
Non-Performing Loans in Emerging Economies - Case Study of India
}

\author{
Dr. K Sriharsha Reddy \\ Assistant Professor \\ Finance and Accounting \\ Institute of Management Technology (IMT-Hyderabad) \\ Tel: 91-40-3046-1673_E-mail: dr.sriharshareddy9@gmail.com \\ Received: May 26, 2015 Accepted: June 14, $2015 \quad$ Published: June 14, 2015 \\ doi:10.5296/ajfa.v7i1.7687 URL: http://dx.doi.org/10.5296/ajfa.v7i1.7687
}

Survey No. 38, Cherlaguda Village, Shamshabad, Hyderabad-5000218, India

\begin{abstract}
Recovery of non-performing assets is considered as one of the biggest problems for the entire banking industry as the earning capacity and profitability of many banks are adversely affected by the high level of NPAs. In this paper an attempt is made to outline the problem of NPAs in Indian banking system. The objectives of the paper are to observe the trends in the incidence of NPAs in Indian banking system, to understand the problem of NPAs in India in comparison with select economies in the world and to outline the policy measures to curtail incidence of NPAs in India. It is observed that the public sector and to some extent the private banks accounts for the bulk of the NPA problem during recent years due to global financial turmoil. Thus, while the policies that have been implemented to address the NPA problem may have been largely successful, there are further steps that can be taken by the RBI as well as by the banks themselves to tackle the problem of NPAs.
\end{abstract}

Keywords: NPAs, Indian banks, Regulatory response, Global financial crisis 


\section{Introduction}

A major problem being observed all over the world in the banking sector is problem of bad loans. First step of building a stable and strong financial system is to minimize non-performing loans. According to World Bank (2014), non-performing loans as proportion of total loans is $24 . .6 \%$ for Ireland, $31.3 \%$ for Greece, $9.5 \%$ for Egypt, $6 \%$ for Russia, 3.6\% for South Africa, 3.2\% for USA, $2.9 \%$ for Brazil and 1\% for China. Non-performing loans have been huge concern for al the nations across the globe. Since the introduction of financial sector reforms in 1992 and second phase of reforms in 1998, the recovery of non-performing assets is considered as one of the biggest problems for the entire banking industry in India. The high level of Non-Performing Assets (NPAs) taints the overall portfolio but puts a burden on the income statement of banks in the form of higher provisions. The earning capacity and profitability of many banks are adversely affected by the high level of NPAs. Though it is not possible to have zero NPAs, a proper understanding of NPAs is required to manage them, with a view to keeping them under control. To understand NPAs, it becomes imperative to understand the determinants of NPAs both from the regulatory as well as managerial angles. For the regulator, NPAs are crucial since they constitute the first trigger of banking crises. For the bank manager, NPAs reduces the bank's profitability, as banks are not allowed to book income on NPAs and, at the same time, required to make provision for such accounts as per the regulator's guidelines. Moreover, managerial and financial resources of the bank are diverted towards resolution of NPA problem causing lost opportunities for more productive use of resources. A bank saddled with NPAs might tend to become risk averse in making new loans, particularly to SMEs. Hence an attempt is made to understand the determinants of the performance of the banks based on asset quality measured by the level of non-performing assets in a bank subsequent to the recommendations made in Narasimham committee report (1998) and Global financial turmoil.

\section{Previous Research and Research Questions}

\subsection{Empirical studies using static econometric models}

In the banking literature, the problem of NPAs has been revisited in several theoretical and empirical studies. Rajaraman, Bhaumik and Bhatia (1999) explained variations in NPAs across Indian banks through differences in operating efficiency, solvency and regional concentration. A considered view is that banks' lending policy could have crucial influence on non-performing loans. Reddy (2004) critically examined various issues pertaining to terms of credit of Indian banks. In this context, it was viewed that 'the element of power has no bearing on the illegal activity. A default is not entirely an irrational decision. Rather a defaulter takes into account probabilistic assessment of various costs and benefits of his decision'. Mohan (2003) emphasized on key lending terms of credit, such as maturity and interest-terms of loans to corporate sector. The Indian viewpoint alluding to the concepts of 'credit culture' owing to Reddy (2004) has an international perspective since several studies in the banking literature agree that banks' lending policy is a major driver of non-performing loans [McGoven (1993), Bloem and Gorters (2001)]. The problem of NPAs is related to several internal factors and external factors confronting the borrowers (Muniappan, 2002). 
The internal factors such as business (product, marketing, etc.) failure, inefficient management, strained labour relations, inappropriate technology/technical problems and external factors such as recession, non-payment in other countries, inputs/power shortage, price escalation, accidents and natural calamities. Rajaraman and Vasishtha (2002) in an empirical study provided an evidence of significant bivariate relationship between an operating inefficiency indicator and the problem loans of public sector banks. Saurina (2002) using panel data on Spanish commercial and saving banks, revealed that various macroeconomic and bank specific factors such as growth in GDP, rapid credit expansion, bank size and capital adequacy ratio influenced the Non-Performing Loans. Berger and Udell (2004) suggested that the time lapse between successive loan bust periods could be a contributing factor for banks to accumulate bad loans in the future and this could be due to the high turn-over of credit officers in the banking system due to various reasons. The pro-cyclical nature of the accumulation of bad loans is due to the fact that during the bust times, the value of collateral erodes and there is an overall decline in the credit standards (Gabriel et al. 2006). Hu et a.l, (2004) found an inverse relationship between bank size and NPLs. Their argument is that large banks have better risk management strategies that usually translate into more superior loan portfolios than their smaller counterparts. Hu et al. (2004) also found that the banks with higher government ownership recorded lower non-performing loans.

\subsection{Empirical studies using dynamic econometric models}

At this point we must stress, that the above studies do not take into account the dynamism which influences incidence of NPAs. First, Salas and Saurina (1999b) have modelled the problem loans ratio of Spanish banks in order to gauge the impact of loan growth policy on bad loans. They were interested in capturing the lag between credit expansion and the emergence of problem loans. Using panel data, they compared the determinants of problem loans of Spanish commercial and savings banks in the period 1985-1997, taking into account both macroeconomic and individual bank level variables. The GDP growth rate, firms, and family indebtedness, rapid past credit or branch expansion, inefficiency, portfolio composition, size, net interest margin, capital ratio, and market power are variables that explain credit risk. However, there are significant differences between commercial and savings banks, which confirm the relevance of the institutional form in the management of credit risk. Their findings raise important bank supervisory policy issues: the use of bank level variables as early warning indicators, the advantages of bank mergers from different regions, and the role of banking competition and ownership in determining credit risk.

Das and Ghosh (2007) examined the factors affecting problem loans of Indian state owned banks for the period 1994-2005, considering dependent lagged variable, macro and bank specific variables influencing NPAs. They found that GDP growth rate at macro level and loan growth rate, operating expenses and bank size at bank level play an important role in influencing problem loans.

Thiagarajan et al (2011), carried out a study to predict the determinants of the credit risk in the Indian commercial banking sector by using an econometric model by utilizing a panel 
data at bank level for 22 public sector banks and 15 private sector banks. They have shown that the lagged non-performing assets had a strong and statistically significant positive influence on the current non-performing assets. There is a significant inverse relationship between the GDP and the credit risk for both public and private sector banks.

In conclusion, the studies which are focused on factors influencing the problem loans of banks, using static or dynamic models are numerous. For this reason, the following table presents some empirical studies and the factors which are identified as responsible for the problem loans.

Table 1. Problem Loans Determinants

\begin{tabular}{|l|l|}
\hline $\begin{array}{l}\text { Proportion of Priority } \\
\text { Sector Advances in } \\
\text { advances }\end{array}$ & $\begin{array}{l}\text { Rajaraman, Bhaumik and Bhatia (1999), Rajaraman and Vasishtha (2002), } \\
\text { Ranjan and Dhal (2003), Chaudhury and Sensarma (2006). Das and Ghosh } \\
(2007), \text { Thiagarajan et al (2011) }\end{array}$ \\
\hline Size & $\begin{array}{l}\text { Chaudhury and Sensarma (2006), Salas and Saurina (1999b), Espinoza R and } \\
\text { Prasad A (2010), Hu. J., Y. Li and Y., Chiu (2004) }\end{array}$ \\
\hline Loan growth & $\begin{array}{l}\text { Chaudhury and Sensarma (2006), Salas and Saurina (1999b), Espinoza R and } \\
\text { Prasad A (2010), }\end{array}$ \\
\hline Operating Expense Ratio & $\begin{array}{l}\text { Chaudhury and Sensarma (2006), Salas and Saurina (1999b), Espinoza R and } \\
\text { Prasad A (2010) }\end{array}$ \\
\hline GNP Growth & $\begin{array}{l}\text { Salas and Saurina (1999b), Fernandez de Lis et al , (2000), Chaudhury and } \\
\text { Sensarma (2006), }\end{array}$ \\
\hline ROA & Chaudhury and Sensarma (2006), \\
\hline CAR & Lyoha and Udegbunam (1999), Chaudhury and Sensarma (2006) \\
\hline Ownership effects & $\begin{array}{l}\text { Hu. J., Y. Li and Y., Chiu, 2004, Chaudhury and Sensarma (2006), Das and } \\
\text { Ghosh (2007) }\end{array}$ \\
\hline
\end{tabular}

Though significant research was undertaken to understand problem loans, impact of global financial crisis on problem loans in Indian context is untouched. Further, impact of bank-specific and macroeconomic variables along with ownership of banks on NPAs is revisited using latest data from 2001- 2012.

\section{Indian Banking Industry and Problem Loans}

The Indian banking system is characterized by different groups of banks categorized into state- owned or public sectors banks, domestic private banks, and foreign banks, which compete amongst each other in almost all areas of banking business. The state-owned public sector banks dominate the banking industry in terms of presence and asset size (chart 1). However, the new domestic private banks, which were set-up in 1995 subsequent to deregulation, have quickly occupied a significant position as compared to the old private banks (Table 2). 


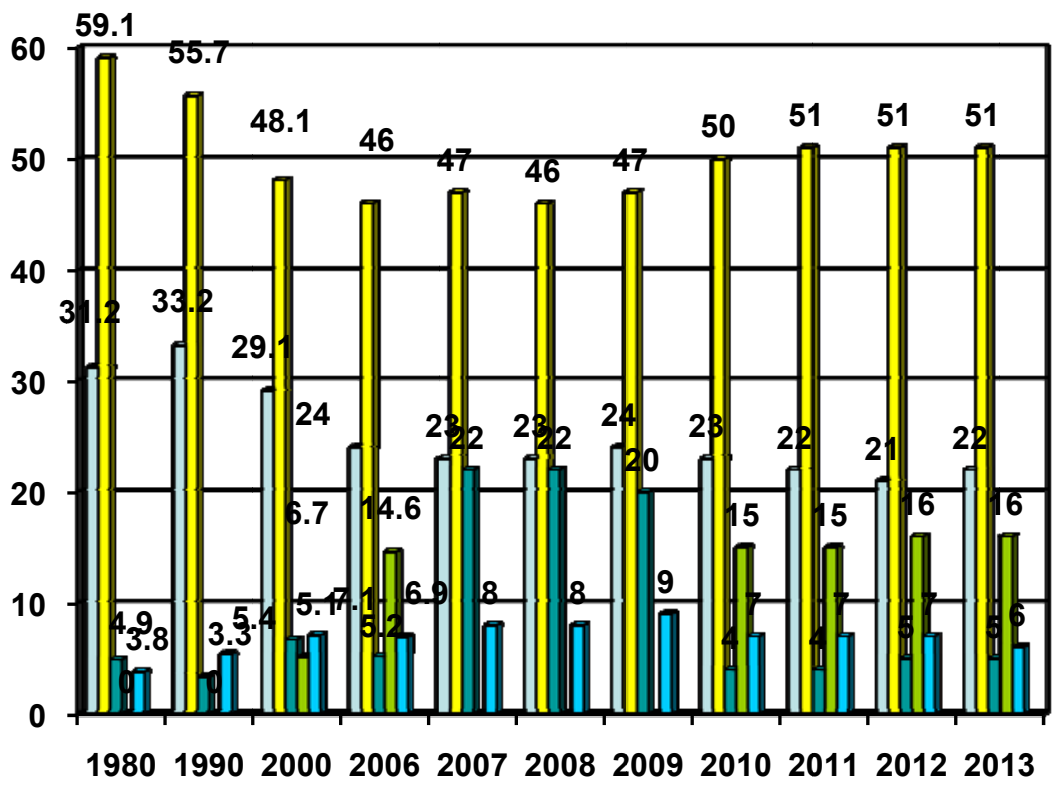

口SBI $\square$ NB $\square$ OPB 口NPB 口FB

\section{Chart 1. Asset Structure of Indian Banking}

Source: Report on Banking Statistical Returns, RBI (2000-2014) deregulation, have quickly occupied a significant position as compared to the old private banks (Table 2). regulation, have quickly occupied a significant position as compared to the old private banks (Table 2).

Table 2. No. of Banks and Asset Structure of Indian Commercial Banking System as at end of March

\begin{tabular}{|c|c|c|c|c|c|c|c|c|c|c|c|c|c|c|}
\hline Yrs & \multicolumn{2}{|c|}{1980} & \multicolumn{2}{|l|}{1985} & \multicolumn{2}{|l|}{1990} & \multicolumn{2}{|l|}{1995} & \multicolumn{2}{|l|}{2000} & \multicolumn{2}{|l|}{2006} & \multicolumn{2}{|l|}{2013} \\
\hline 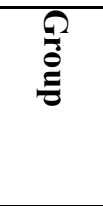 & 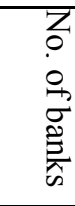 & $\begin{array}{l}\partial^{\circ} \\
\overrightarrow{0} \\
\rightarrow \\
\stackrel{0}{0}\end{array}$ & 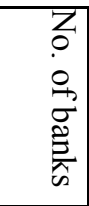 & $\begin{array}{l}\stackrel{0}{0}^{\circ} \\
\overrightarrow{0} \\
-1 \\
\stackrel{0}{0}\end{array}$ & 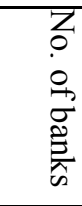 & $\begin{array}{l}0^{\circ} \\
\overrightarrow{0} \\
-1 \\
\stackrel{0}{\vec{D}}\end{array}$ & 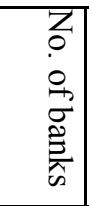 & $\begin{array}{l}\sigma^{\circ} \\
\overrightarrow{0} \\
\overrightarrow{0} \\
\stackrel{0}{\vec{D}}\end{array}$ & 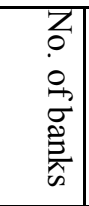 & $\begin{array}{l}\stackrel{\circ}{0} \\
\overrightarrow{0} \\
\overrightarrow{0} \\
\stackrel{0}{\partial}\end{array}$ & 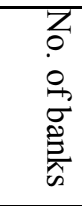 & $\begin{array}{l}0 \\
0 \\
0 \\
0 \\
0 \\
\hat{0}\end{array}$ & 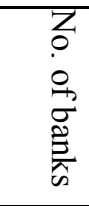 & $\begin{array}{l}0 \\
\overrightarrow{0} \\
\overrightarrow{1} \\
0 \\
\stackrel{0}{0}\end{array}$ \\
\hline SBI & 8 & 31.2 & 8 & 32.0 & 8 & 33.2 & 8 & 29.5 & 8 & 29.1 & 8 & 24 & 6 & 22 \\
\hline NB & 20 & 59.1 & 20 & 57.8 & 20 & 55.7 & 19 & 53.3 & 19 & 48.1 & 20 & 46 & 20 & 51 \\
\hline OPB & 34 & 4.9 & 32 & 4.2 & 25 & 3.3 & 24 & 5.8 & 24 & 6.7 & 19 & 5.2 & 13 & 5 \\
\hline NPB & - & ----- & - & ---- & - & ---- & 8 & 1.4 & 8 & 5.1 & 8 & 14.6 & 7 & 16 \\
\hline FB & 13 & 3.8 & 20 & 4.0 & 22 & 5.4 & 27 & 7.1 & 42 & 7.1 & 29 & 6.9 & 43 & 6 \\
\hline SCB & 75 & 100 & 80 & 100 & 75 & 100 & 86 & 100 & 101 & 100 & 84 & 100 & 89 & 100 \\
\hline Rs Crs & \multicolumn{2}{|c|}{58,238} & \multicolumn{2}{|c|}{$1,36,681$} & \multicolumn{2}{|c|}{$2,92,770$} & \multicolumn{2}{|c|}{$5,29,876$} & \multicolumn{2}{|c|}{$11,52,604$} & \multicolumn{2}{|c|}{$28,75,520$} & \multicolumn{2}{|c|}{$95,73,334$} \\
\hline
\end{tabular}

Source: Report on Banking Statistical Returns, RBI (2000-2014) 


\section{Macrothink}

Our economy was deregulated and liberalized to attract foreign capital in early 1990s. Since that time many financial institutions entered into India with strategic ideas. Prior to 1990s our public sector banks and other banks concentrated more on social lending and had accumulated huge non performing assets. The financial statements revealed that most of the PSBs profitability was affected due to mounting of poor quality assets later pronounced as non-performing assets. It was identified by Narasimham Committee-I (1991) and recommended prudential norms on income recognition, asset classification and provisioning on par with international standard set by BIS (Bank for international settlement).

While it is often argued that the banking sector reforms in India were successful in enhancing efficiency and productivity of banks (Sensarma 2006), one of the problems faced by Indian banking is NPAs problem. As on march $31^{\text {st }} 2013$ the gross NPAs to gross advances ratio of all SCBs in India was 3.4 while net NPAs (net of provisioning) to Net advances ratio was 1.7 (Table 3). NPA ratios have been declining over the years for all bank groups. Net NPA ratio was the highest for public sector banks at end-March 2013 (1.7 per cent), followed by foreign banks, old private banks, and new private banks. Furthermore, the problem of NPAs was more severe for domestic banks as compared to that for foreign banks because 93 per cent of the assets (Table 2), 95 percent of gross advances (Table 3B) and 95 percent of gross NPAs (Table 3A) of Indian banking industry are with public sector banks and domestic private banks. Thus, it is extremely crucial to understand the asset quality of public and domestic private banks in India for the financial stability of the economy. Moreover, because of their significant contribution to domestic industrial credit and mobilizing deposits, the issue of prudent lending and effective credit risk management is of paramount importance for these banks. 


\section{Macrothink Institute ${ }^{\text {TM }}$}

Table 3. Incidence of Gross and Net NPAs of SCBs (at end-March)

\begin{tabular}{|c|c|c|c|c|c|c|c|c|c|c|}
\hline \multirow[t]{2}{*}{ Year } & \multicolumn{5}{|c|}{$\%$ of Gross NPAs to Gross Advances } & \multicolumn{5}{|c|}{$\begin{array}{l}\% \text { of Net NPAs to Net } \\
\text { Advances }\end{array}$} \\
\hline & SCB & PSB & OPB & NPB & FB & SCB & PSB & $\mathrm{OPB}$ & NPB & FB \\
\hline 1998 & 14.4 & 16.0 & 10.9 & 3.5 & 6.4 & 7.3 & 8.2 & 6.5 & 2.6 & 2.2 \\
\hline 1999 & 14.7 & 15.9 & 13.1 & 6.2 & 7.6 & 7.6 & 8.1 & 9.0 & 4.5 & 2.9 \\
\hline 2000 & 12.8 & 14.0 & 11.3 & 4.2 & 7.0 & 6.8 & 7.4 & 7.3 & 2.9 & 2.4 \\
\hline 2001 & 11.4 & 12.4 & 10.9 & 5.1 & 6.8 & 6.2 & 6.7 & 7.3 & 3.1 & 1.8 \\
\hline 2002 & 10.4 & 11.1 & 11.0 & 8.9 & 5.4 & 5.5 & 5.8 & 7.1 & 4.9 & 1.9 \\
\hline 2003 & 8.8 & 9.4 & 8.9 & 7.6 & 5.3 & 4.4 & 4.5 & 5.5 & 4.6 & 1.8 \\
\hline 2004 & 7.2 & 7.8 & 7.6 & 5.0 & 4.6 & 2.9 & 3.0 & 3.8 & 2.4 & 1.5 \\
\hline 2005 & 5.2 & 5.5 & 6.0 & 3.6 & 2.8 & 2.0 & 2.1 & 2.7 & 1.9 & 0.9 \\
\hline 2006 & 3.3 & 3.7 & 4.3 & 1.7 & 1.9 & 1.2 & 1.3 & 1.6 & 0.8 & 0.8 \\
\hline 2007 & 2.6 & 2.8 & 2.4 & & 1.9 & 1.0 & 1.1 & 1.0 & & 0.7 \\
\hline 2008 & 2.4 & 2.3 & 2.7 & & 1.9 & 1.0 & 1.0 & 1.1 & & 1.2 \\
\hline 2009 & 2.4 & 2.1 & 3.2 & & 4.3 & 1.1 & 0.7 & 1.5 & & 1.7 \\
\hline 2010 & 2.5 & 2.3 & 3.0 & & 4.3 & 1.1 & 1.1 & 0.8 & 1.1 & 1.8 \\
\hline 2011 & 2.4 & 2.3 & 2.5 & & 2.5 & 1.0 & 1.2 & 0.5 & 0.6 & 0.6 \\
\hline 2012 & 2.9 & 3.2 & 2.1 & & 2.7 & 1.4 & 1.7 & 0.6 & 0.5 & 0.6 \\
\hline 2013 & 3.4 & 3.8 & 1.9 & & 3 & 1.7 & 2 & 0.8 & 0.4 & 1 \\
\hline
\end{tabular}

Source: Report on Banking Statistical Returns, RBI (2000-2014)

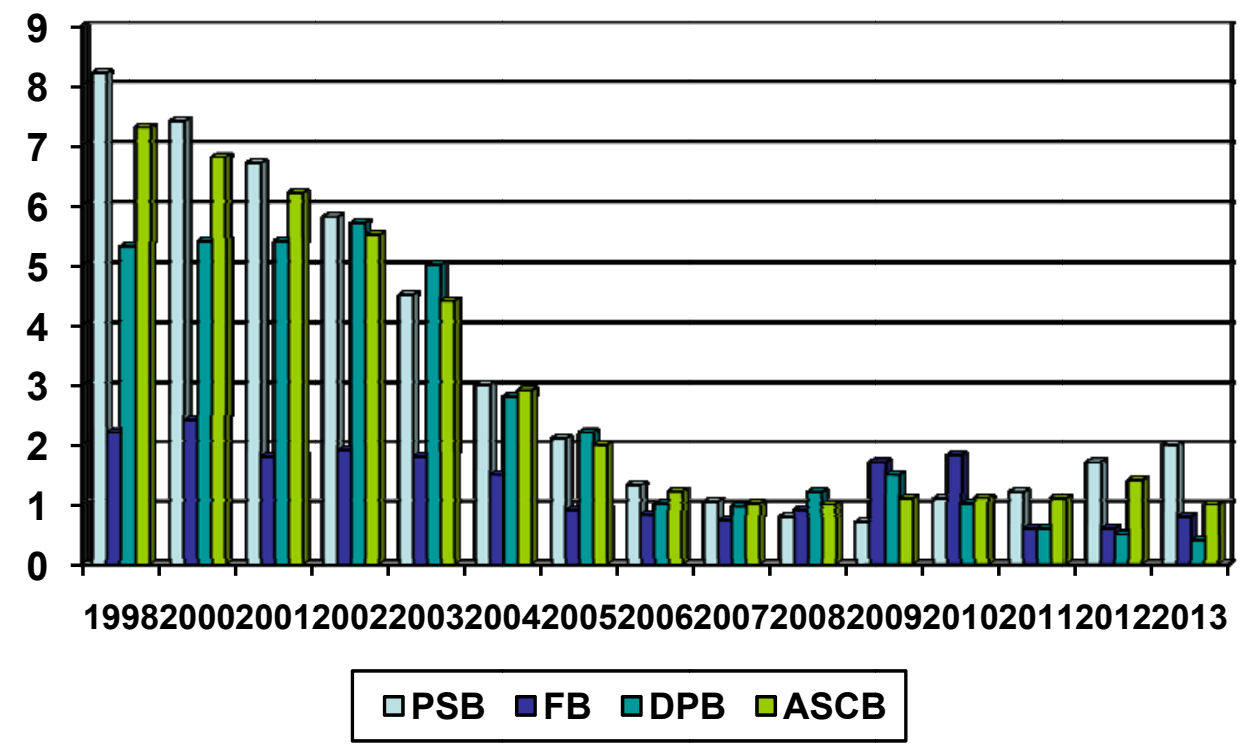

Chart 2. NPA s of Scheduled Commercial Banks as Percent of Net Advances

Source: Report on Banking Statistical Returns, RBI (2000-2014) 
Table 3A. Incidence of Gross NPAs of SCBs (at end-March)

\begin{tabular}{|l|l|l|l|l|l|l|l|l|}
\hline & \multicolumn{4}{|c|}{ Gross NPAs in 00' crs } & \multicolumn{3}{|c|}{ Proportion of Gross NPAs in Total } \\
\hline YEAR & PSB & PB & FB & SCB & PSB & PB & FB & ASCB \\
\hline 2006 & 413.78 & 77.74 & 20.90 & 512.42 & $81 \%$ & $15 \%$ & $4 \%$ & $100 \%$ \\
\hline 2007 & 384.25 & 92.39 & 24.52 & 501.16 & $77 \%$ & $18 \%$ & $5 \%$ & $100 \%$ \\
\hline 2008 & 396.06 & 129.76 & 31.18 & 556.99 & $71 \%$ & $23 \%$ & $6 \%$ & $100 \%$ \\
\hline 2009 & 440.32 & 168.88 & 72.94 & 682.13 & $65 \%$ & $25 \%$ & $11 \%$ & $100 \%$ \\
\hline 2010 & 572.93 & 173.84 & 71.28 & 818.05 & $70 \%$ & $21 \%$ & $9 \%$ & $100 \%$ \\
\hline 2011 & 710.80 & 179.72 & 50.65 & 941.17 & $76 \%$ & $19 \%$ & $5 \%$ & $100 \%$ \\
\hline 2012 & 1124.89 & 183.15 & 62.92 & 1370.96 & $82 \%$ & $13 \%$ & $5 \%$ & $100 \%$ \\
\hline 2013 & $1,558.90$ & 199.92 & 79.72 & $1,838.54$ & $85 \%$ & $11 \%$ & $4 \%$ & $100 \%$ \\
\hline
\end{tabular}

Source: Report on Banking Statistical Returns, RBI (2000-2014)

Table 3B. Incidence of Gross Advances of SCBs (at end-March)

\begin{tabular}{|l|l|l|l|l|l|l|l|l|}
\hline & \multicolumn{3}{|l}{ Gross Advances in 00' crs } & \multicolumn{3}{l|}{$\begin{array}{l}\text { Proportion of Gross Advances in } \\
\text { Total }\end{array}$} \\
\hline YEAR & PSB & PB & FB & SCB & PSB & PB & FB & ASCB \\
\hline 2006 & 10708.72 & 3037.93 & 988.62 & 14735.27 & $73 \%$ & $21 \%$ & $7 \%$ & $100 \%$ \\
\hline 2007 & 13737.77 & 3918.69 & 1278.67 & 18935.13 & $73 \%$ & $21 \%$ & $7 \%$ & $100 \%$ \\
\hline 2008 & 16963.33 & 4723.45 & 1629.99 & 23316.78 & $73 \%$ & $20 \%$ & $7 \%$ & $100 \%$ \\
\hline 2009 & 20999.38 & 5196.55 & 1697.14 & 27893.07 & $75 \%$ & $19 \%$ & $6 \%$ & $100 \%$ \\
\hline 2010 & 25123.58 & 5845.76 & 1674.39 & 32643.72 & $77 \%$ & $18 \%$ & $5 \%$ & $100 \%$ \\
\hline 2011 & 30598.70 & 7323.10 & 1993.21 & 39915.01 & $77 \%$ & $18 \%$ & $5 \%$ & $100 \%$ \\
\hline 2012 & 35503.89 & 8804.45 & 2347.10 & 46655.44 & $76 \%$ & $19 \%$ & $5 \%$ & $100 \%$ \\
\hline 2013 & $40,558.74$ & $10,466.65$ & $2,686.12$ & $53,711.51$ & $76 \%$ & $19 \%$ & $5 \%$ & $100 \%$ \\
\hline
\end{tabular}

Source: Report on Banking Statistical Returns, RBI (2000-2014)

\section{Problem Loans- A Cross Country Analysis}

To get an idea of the scale of India's bad loans problem in comparison with the rest of the world, a comparison of incidence of NPAs in India with that of some selected countries across geographical regions is made (table 4). It is observed that the incidence of NPAs has come down significantly from 2000 till 2013 for almost all countries reported above India in the table. From 2007, Gross NPAs have increased for some of the countries due to hard-hit recession and global financial crisis. Moreover, in 2013 incidence of NPAs in India appears to be high in comparison to emerging economies such as China (1), Thailand (2.3), Malaysia (1.8), Korea (0.7) and Turkey (2.6). Developed countries such as Australia (1.4), and Canada (0.6), expectedly, have the lowest levels of NPAs. Surprisingly, problem of NPAs is less severe in India when compared to developed economies such as France (4.3) and emerging economies such as Russia (6). The major reason for this trend can be attributed to the global financial crisis faced by the developed economies and conservative, watchful policies adopted by the RBI in India. 


\section{MInstitute Macrothink}

Table 4. Cross-Country Comparison of Gross Non-Performing Loans to Total Loans

\begin{tabular}{|c|c|c|c|c|c|c|c|c|c|c|c|c|c|}
\hline Country & 2001 & 2002 & 2003 & 2004 & 2005 & 2006 & 2007 & 2008 & 2009 & 2010 & 2011 & 2012 & 2013 \\
\hline Finland & 0.6 & 0.5 & 0.5 & 0.4 & 0.3 & 0.2 & 0.3 & 0.4 & 0.6 & 0.6 & 0.5 & 0.5 & 0.5 \\
\hline Canada & 1.5 & 1.6 & 1.2 & 0.7 & 0.5 & 0.4 & 0.4 & 0.8 & 1.3 & 1.2 & 0.8 & 0.6 & 0.6 \\
\hline Sweden & 1.5 & 1.2 & 1.9 & 1.1 & 0.8 & 0.8 & 0.1 & 0.5 & 0.8 & 0.8 & 0.7 & 0.7 & 0.6 \\
\hline China & 29.8 & 26 & 20.4 & 13.2 & 8.6 & 7.1 & 6.2 & 2.4 & 1.6 & 1.1 & 1 & 0.9 & 1 \\
\hline Singapore & 8 & 7.7 & 6.7 & 5 & 3.8 & 2.8 & 1.5 & 1.4 & 2 & 1.4 & 1.1 & 1 & 0.9 \\
\hline Venezuela, RB & 7 & 9.2 & 7.7 & 2.8 & 1.2 & 1.1 & 1.2 & 1.9 & 3 & 3.4 & 1.4 & 1.2 & 0.7 \\
\hline Argentina & 13.1 & 18.1 & 17.7 & 10.7 & 5.2 & 3.4 & 2.7 & 2.7 & 3 & 1.8 & 1.2 & 1.5 & 1.7 \\
\hline Korea, Rep. & 3.4 & 2.4 & 2.6 & 1.9 & 1.2 & 0.8 & 0.7 & 1.1 & 1.2 & 1.9 & 1.4 & 1.5 & 0.7 \\
\hline Bolivia & 16.2 & 17.7 & 16.7 & 14 & 11.3 & 8.7 & 5.6 & 4.3 & 3.5 & 2.2 & 1.7 & 1.7 & $1-$ \\
\hline Australia & 0.6 & 0.4 & 0.3 & 0.2 & 0.2 & 0.6 & 0.6 & 1.3 & 2 & 2.2 & 2 & 1.9 & 1.4 \\
\hline Indonesia & 31.9 & 24 & 6.8 & 4.5 & 7.4 & 6.1 & 4 & 3.2 & 3.3 & 2.5 & 2.1 & 2.1 & 1.5 \\
\hline Malaysia & 17.8 & 15.9 & 13.9 & 11.7 & 9.6 & 8.5 & 6.5 & 4.8 & 3.6 & 3.4 & 2.7 & 2.2 & 1.8 \\
\hline Mexico & 5.1 & 3.7 & 3.2 & 2.5 & 1.8 & 1.8 & 2.4 & 3 & 2.8 & 2 & 2.1 & 2.2 & 3.2 \\
\hline Chile & 1.6 & 1.8 & 1.6 & 1.2 & 0.9 & 0.8 & 0.8 & 1 & 2.9 & 2.7 & 2.4 & 2.4 & 2.1 \\
\hline Israel & 8.2 & 2.4 & 2.6 & 2.5 & 2.3 & 2 & 1.5 & 1.5 & 1.4 & 3.1 & 2.5 & 2.4 & 2.4 \\
\hline Philippines & 27.7 & 26.5 & 16.1 & 14.4 & 10 & 7.5 & 5.8 & 4.5 & 3.5 & 3.4 & 2.6 & 2.4 & 3 \\
\hline Turkey & 29.3 & 12.7 & 11.5 & 6 & 5 & 3.9 & 3.3 & 3.4 & 5 & 3.5 & 2.6 & 2.5 & 2.6 \\
\hline Austria & 2.3 & 3 & 3 & 2.7 & 2.6 & 2.7 & 2.2 & 1.9 & 2.3 & 2.8 & 2.7 & 2.7 & 2.9 \\
\hline Thailand & 11.5 & 15.7 & 13.5 & 11.9 & 9.1 & 8.1 & 7.9 & 5.7 & 5.3 & 3.9 & 2.9 & 2.7 & 2.3 \\
\hline Colombia & 9.7 & 8.7 & 6.8 & 3.3 & 2.7 & 2.7 & 3.2 & 3.9 & 4 & 2.9 & 2.5 & 3 & 2.8 \\
\hline Japan & 8.4 & 7.4 & 5.2 & 2.9 & 1.8 & 1.5 & 1.5 & 1.4 & 1.6 & 2.5 & 2.4 & - & 2.3 \\
\hline India & 11.4 & 10.4 & 8.8 & 7.2 & 5.2 & 3.3 & 2.7 & 2.4 & 2.4 & 2.5 & 2.3 & 3 & 3.8 \\
\hline Netherlands & 2.3 & 2.4 & 2 & 1.5 & 1.2 & & & 1.7 & 3.2 & 2.8 & 2.7 & 3.1 & 3.2 \\
\hline Brazil & 5.6 & 4.5 & 4.1 & 2.9 & 3.5 & 3.5 & 3 & 3.1 & 4.2 & 3.1 & 3.5 & 3.6 & 2.9 \\
\hline Belarus & 14.9 & 9 & 3.7 & 2.8 & 3.1 & 2.8 & 1.9 & 1.7 & 4.2 & 3.5 & 4.2 & 3.9 & 4.6 \\
\hline United States & 1.3 & 1.4 & 1.1 & 0.8 & 0.7 & 0.8 & 1.4 & 3 & 5.4 & 4.9 & 4.1 & 3.9 & 3.2 \\
\hline South Africa & 3.1 & 2.8 & 2.4 & 1.8 & 1.5 & 1.1 & 1.4 & 3.9 & 5.9 & 5.8 & 4.7 & 4.6 & 3.6 \\
\hline Czech Republic & 13.7 & 8.1 & 4.9 & 4 & 3.9 & 3.6 & 2.4 & 2.8 & 4.6 & 5.4 & 5.2 & 5.1 & 5.2 \\
\hline Russian Federation & 6.2 & 5.6 & 5 & 3.8 & 2.6 & 2.4 & 2.5 & 3.8 & 9.5 & 8.2 & 6.6 & 6.7 & 6 \\
\hline United Arab Emirates & 15.7 & 15.3 & 14.3 & 12.5 & 8.3 & 6.3 & 2.9 & 2.3 & 4.3 & 5.6 & 6.2 & 7.6 & 8.4 \\
\hline Poland & & 21.1 & 21.2 & 14.9 & 11 & 7.4 & 5.2 & 4.4 & 7.9 & 8.8 & 8.2 & 8.4 & 5.2 \\
\hline Portugal & 2.1 & 2.3 & 2.4 & 2 & 1.5 & 1.3 & 2.8 & 3.6 & 4.8 & 5.2 & 7.5 & 9 & 11 \\
\hline Egypt, Arab Rep. & 16.9 & 20.2 & 24.2 & 23.6 & 26.5 & 18.2 & 19.3 & 14.8 & 13.4 & 13.6 & 10.9 & 10.7 & 9.5 \\
\hline Croatia & 7.3 & 10.2 & 8.9 & 7.5 & 6.2 & 5.2 & 4.8 & 4.9 & 7.7 & 11.1 & 12.3 & 13.2 & 15.4 \\
\hline Hungary & 2.7 & 2.9 & 2.6 & 2.7 & 2.3 & 2.6 & 2.3 & 3 & 6.7 & 9.8 & 13.4 & 15.8 & 17.6 \\
\hline Romania & 3.3 & & 8.3 & 8.1 & 2.6 & 1.8 & 2.6 & 2.8 & 7.9 & 11.9 & 14.3 & 16.8 & 21.6 \\
\hline Bulgaria & 3.3 & 2.6 & 3.2 & 2 & 2.2 & 2.2 & 2.1 & 2.5 & 6.4 & 11.9 & 14.9 & 16.9 & - \\
\hline Greece & 5.6 & 5.5 & 7 & 7 & 6.3 & 5.4 & 4.5 & 5 & 7.7 & 10.4 & 14.4 & 17.2 & 31.3 \\
\hline Ireland & 1 & 1 & 0.9 & 0.8 & 0.7 & 0.7 & 0.8 & 2.6 & 9 & 8.6 & 16.1 & 18.7 & 24.6 \\
\hline
\end{tabular}


Source: World Bank Group (2014), IMF, S., \& Soundness, R. F. (2013)

http://data.worldbank.org/indicator/FB.AST.NPER.ZS?order=wbapi_data_value_2013\%20wbapi_data_value\%20wbapi_dat a_value-last\&sort $=$ asc

Clearly, while India's bad loans problem is not as severe as in several other comparable economies, there is a need to manage NPAs and reduce them further. The problem of NPAs when ignored has the potential of causing economic and financial deterioration of an economy. To tackle the problem, the regulators have initiated several policy responses, which are discussed in the next section.

\section{Regulatory Response to NPAs}

Several measures have been implemented by the RBI and the Government of India to contain the level of NPAs. These include Debt Recovery Tribunals (DRTs), Corporate Debt Restructuring (CDR) scheme, Securitization and Reconstruction Financial Assets and Enforcement of Security Interest (SAFAESI) Act, and Asset Reconstruction Companies (ARCs). Settlement advisory committees have also been formed at regional and head office levels of commercial banks. In order to provide an additional option to banks and to develop a healthy secondary market for NPAs, guidelines on sale/purchase of NPAs were issued in July 2005 for those institutions which are not either Securitization Companies or Reconstruction Companies.

Some other steps that have been taken to reduce NPAs are:improvement in supervisory mechanism through prompt corrective action (PCA), sharing of borrower information among banks by setting up of Credit Information Bureau of India Limited(CIBIL) and rewarding low NPA banks with freedom in dividend payments to the shareholders. With regard to the first measure mentioned, RBI initiates some structured and discretionary actions against those banks which have hit certain 'trigger points' on three parameters, viz. CRAR, net NPAs and ROA. The two trigger points for NPAs are 10 per cent and 15 per cent beyond which the concerned bank has to implement measures such as a special drive to reduce NPAs, review its loan and credit-risk management policies, not enter new lines of business etc. With regard to the second measure mentioned above, CIBIL is a depository of information containing credit history of commercial and consumer borrowers that banks can use in evaluating their risks and taking their credit decisions. With regard to the last measure mentioned, RBI has granted general permission to those banks to declare dividends (subject to a cap of 40 per cent on dividend payout ratio) for the accounting year ended 31 march, 2005 onwards, which comply with: (i) CRAR of at least 9 per cent for preceding two years and the accounting year for which it proposes to declare dividend; and (ii) net NPA ratio of less than 7 per cent. In case any bank does not meet the above CRAR norm, but has CRAR of at least 9 per cent for the accounting year for which it proposes to declare dividend, it is allowed to declare dividend, provided its net NPA ratio is less than 5 per cent. Thus, banks have a variety of options and legislations to take recourse in order to resolve their bad loans problem. There are also supportive supervisory mechanisms available with the RBI and incentives provided to banks for reducing the level of NPAs. 


\subsection{The Debt Recovery Tribunal Act (DRTAct)}

Coincident with the first phase of banking sector reforms, one of the first legislations to address the problem of NPAs in India was the recovery of debts due to banks and financial institutions act, 1993, which came into force on $24^{\text {th }}$ June, 1993. The act recommended setting up of DRTs for speedy adjudication and recovery of debts (where the claim is more than Rs 10 Lakh) due to banks and financial institutions (FIs). The act also recommended setting up debt recovery appellate tribunals (DRATs) to entertain appeals against any order made by a DRT. Alongside this, the RBI actively promoted the compromise settlements or one time settlements (OTS) to encourage out-of-court settlements of bad debts. Lok adalats (or people's courts), organized by DRTs, help banks to settle disputes involving small loans, but the ceiling has now been raised from Rs 5 lakh to Rs 20 lakh.

As on 31 March, 2013, there were 29 DRTs and one DRAT in India. During 2013, 8,40,691 cases involving an amount of Rs 6600 Crs was filed in Lokadalats, out of which an amount of Rs 400 Crs was recovered (RBI 2012-13). In addition to the actual recovery, DRTs are one of the main factors behind the defaulters coming forward for OTS with the banks and FIs. During 2013, 13,408 cases involving an amount of Rs 31000 Crs was filed in DRTs, out of which an amount of Rs 4400 Crs was, recovered (RBI 2012-13).

\subsection{The Corporate Debt Reconstruction Scheme (CDR)}

On 23 august, 2001, the RBI issued guidelines to banks and financial institutions to implement CDR system. CDR is a voluntary and non-statutory arrangement between lenders and borrowers for timely and orderly restructuring of debts which are affected by certain internal and external factors. The Corporate Debt Restructuring (CDR) cell has restructured 638 cases having aggregate debt of Rs 446156 crs between August 2001 and September 2014 and 505 cases amounting Rs 367607 crs were approved (CDR Performance, 2014).

\subsection{The SARFAESI Act and ARC}

The SARFAESI act was passed on $21^{\text {st }}$ June, 2002 to enable banks and FIs to attach the assets of defaulting borrowers without having to approach the courts for recovery. The act provides for the sale of financial assets by banks and financial institutions to Securitization Companies (SCs) and ARCs. SCs and ARCs are institutions that acquire NPAs from FIs and bank with the objective of recovery thereby taking up their burden of NPAs. The first ARC, Asset Reconstruction Company (India) limited (ARCIL) was also set up under the act and commenced business on $29^{\text {th }}$ August, 2003. This act was later amended through the Enforcement of Security Interest and Recovery of Debts (Amendment) act 2004, which was passed on $29^{\text {th }}$ December, 2004. The new act made it mandatory for the borrowers who appeal to DRAT to deposit upfront 50 percent of the amount involved in the dispute. This is expected to restrict borrowers from delaying repayments under the cover of trivial cases. Recoveries under the SARFAESI act, 2002 amounted to Rs 18500 crore as at end-March 2013 (Table 5) 
Table 5. NPAs Recovered by Scheduled Commercial Banks through Various Channels

\begin{tabular}{|c|c|c|c|c|c|c|c|c|c|c|c|c|c|c|}
\hline & & 2010 & & & & 2011 & & & & 2012 & & & 2013 & \\
\hline 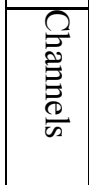 & $\begin{array}{l}\overrightarrow{0} \\
\overrightarrow{0} \\
\overrightarrow{0} \\
2\end{array}$ & 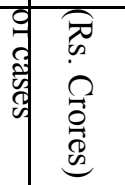 & 自 & $\begin{array}{l}\overrightarrow{0} \\
0 \\
0 \\
0 \\
0 \\
0 \\
0 \\
2\end{array}$ & 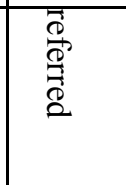 & 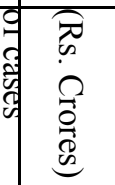 & 羊 & $\begin{array}{l}\overrightarrow{0} \\
0 \\
0 \\
0 \\
0 \\
0 \\
0 \\
0\end{array}$ & $\begin{array}{l}\overrightarrow{0} \\
\overrightarrow{0} \\
\overrightarrow{0} \\
\overrightarrow{8}\end{array}$ & $\begin{array}{l}\text { त्र } \\
0 \\
0 \\
0 \\
0 \\
0 \\
0 \\
0\end{array}$ & 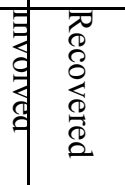 & $\begin{array}{l}\overrightarrow{0} \\
\stackrel{0}{0} \\
\overrightarrow{0} \\
0\end{array}$ & $\begin{array}{l}\overrightarrow{0} \\
0 \\
0 \\
0 \\
0 \\
0 \\
0 \\
0\end{array}$ & 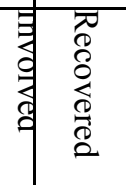 \\
\hline $\begin{array}{l}\text { Lok } \\
\text { Adal } \\
\text { ats }\end{array}$ & 778833 & 7235 & & 12 & 616018 & 5254 & & 151 & $4,76,073$ & 1700 & 200 & $8,40,691$ & 6600 & 400 \\
\hline $\begin{array}{l}\text { DRT } \\
\text { s }\end{array}$ & 6019 & 9797 & & 133 & 12872 & 14092 & & 3930 & 13,365 & 24100 & 4100 & 13,408 & 31000 & 4400 \\
\hline $\begin{array}{l}\text { SAR } \\
\text { FAE } \\
\text { SI } \\
\text { Act }\end{array}$ & 78366 & 14249 & & 269 & 118642 & 30604 & & 11561 & $1,40,991$ & 35300 & 10100 & $1,90,537$ & 68100 & 18500 \\
\hline
\end{tabular}

Source: Report of Trends and Progress of Banking in India by RBI (2010-2014)

\section{Determinants of problem loans}

\subsection{Priority Sector Advances}

Priority sector advances is a significant feature of Indian banking industry since nationalization of banks in 1969 and proportion of priority sector loans in total loans (PRADV) is included as a determinant in order to account for the argument that the priority sector loans are responsible for the most number of defaults (Narasimham committee report 1998). While it is also argued that it is the non-priority sector that contributes to the biggest defaults in terms of size, controlling for this variable appears sufficient to take care of the nature of the sector to which most of the loans are given as a determinant of NPAs (Chaudhury and Sensarma, 2006, Rajaraman, Bhaumik and Bhatia)

H1: The banks' proportion of priority sector advances in total advances is positively correlated with problem loans

\subsection{Size}

One of the most discussed features of the banks influencing problem loans is size of the bank. Size (SIZE) taken as logarithm of assets acts as a control for whether bigger banks are more vulnerable to the NPA problem than smaller banks (Chaudhury and Sensarma 2006, Salas and Saurina 1999, Espinoza and Prasad 2010, Hu et al 2004, Ranjan and Dhal (2003))

\section{H2: The bank size is negatively correlated with problem loans}

\subsection{Capital Adequacy}

Capital adequacy ratio (CAR) is the ratio between bank's capital and risk weighted assets. It is considered to account for the importance of capitalization in causing NPAs. It is expected 
that adequately capitalized banks would exhibit lower NPAs (Lyoha and Udegbunam 1999, Rajaraman, Bhaumik and Bhatia 1999, Chaudhury and Sensarma 2006)

\section{H3: The bank's capital adequacy is negatively correlated with problem loans}

\subsection{Profitability}

Profitability of the banks can be captured using return on assets ratio which is the ratio between the net profit after tax and average assets. It is argued that profitable banks will have quality orientation towards credit management and less vulnerable to problem loans (Narasimham committee report 1998). Return on Assets (ROA) is considered with an expectation that the more profitable banks would have less NPAs (Chaudhury and Sensarma 2006).

\section{H4: Bank's profitability is negatively correlated with problem loans}

\subsection{Cost Inefficiency}

Inefficient banks performing poor screening and monitoring of borrowers will tend to have inferior portfolio quality. Kwan and Eisenbis (1997) demonstrate that higher levels of bank inefficiency can lead to an increase in problem loans. To capture bank level inefficiency, operating cost ratio (OCR) which is the ratio between operating expenses and total assets is considered. It is included with an expectation that NPAs will increase with high operating costs or low cost efficiency (Chaudhury and Sensarma 2006, Salas and Saurina 1999, Espinoza and Prasad 2010).

\section{H5: Bank's inefficiency is positively correlated with problem loans}

\subsection{Credit Growth}

A rapid credit expansion is considered as one of the most important causes of problem loans (Caprio et al , 1994). Growth in advances (GRADV) is included to understand the aggressiveness of a bank in its lending behaviour. More aggressive banks may push riskier loans and hence end up with more NPAs (Clair 1992). On the other hand, banks which concentrate on more lending will develop expertise in effectively managing credit risk and hence exhibit lower NPAs. Therefore, the role of lending aggressiveness in NPAs is ambiguous. GRADV $\mathrm{t}_{\mathrm{t}-1}$ and GRADV $\mathrm{t}_{\mathrm{t}-2}$ are considered to capture the lag effects of growth rates in advances on NPAs ( Salas and Saurina 1999, Espinoza R and Prasad A 2010, Das A. \& Ghosh S 2007).

\section{H6: Bank's credit growth is correlated with problem loans}

\subsection{Congenial Macroeconomic environment}

The empirical evidence tends to suggest that banks problem loans are closely related to economic activity (Salas and Saurina 1999, Fernandez de Lis et al 2000, Chaudhury and Sensarma 2006, Das A. \& Ghosh S 2007). When growth slows or even turns negative, firms and households reduce their cash inflows and makes it difficult for them to repay the loans. Banks anticipate that if a recession occurs, firms and households will encounter 
liquidity shortages, which would raise the likelihood of delays in the fulfillment of their financial obligations (Jimenez and Saurina, 2006). Growth in Gross National Product at constant prices (GGNP) is included with an assumption that when the macro-economic conditions are sound and GNP growth is higher, the level of NPAs would be lower.

\section{H7: Growth in gross national product is negatively correlated with problem loans}

\section{Data and Econometric Methodology}

To assess the impact and to identify the determinants of NPAs in Indian banking we need to estimate a relationship of the following form using bank level data and macroeconomic across several years.

$$
\mathrm{NPA}_{\mathrm{it}}=\alpha+\beta \mathrm{X}_{\mathrm{it}}+\varepsilon_{\mathrm{it}}
$$

Here, X represents factors, which are supposed to determine NPAs, i and t represents bank and year respectively and $\varepsilon$ unexplained residual. The financial data of banks are taken from "Statistical Tables Relating to Banks" (2001-2012) published by RBI and data on macro-economic variables have been obtained from RBI website. Our data set consists of 41 public and domestic private sector banks and period of study is from 2001-2012. This kind of dataset allows us to look at, a certain number of units over time, mainly through fixed or random effects models and dynamic econometric models. Specifically, according to relevant econometric literature (e.g.. Hsiao, 1985; Hsiao, 2014; Ozkan, 2001; Gaud et al., 2005; Wooldridge, 2006; Colin and Trivedi, 2005; Baltagi, 1995, Stavros et al 2011) in order to achieve sufficient estimates within this short run sample period (2001-2012), it is necessary to use panel dataset. Foreign banks are not included in the present study as level of NPAs was never a problem in the case of foreign banks (Table 3), proportion of assets in Indian banking industry is only $7 \%$ (Table 2 ) and foreign banks adopt the strategy of 'Intensive banking ' as against the strategy of 'extensive banking' by public sector banks.

The analysis consists of estimating different versions of the NPA equation using fixed effects and random effects panel regression using STATA 12. The pooled OLS estimation of equation (1) may yield unsatisfactory results due to the nature of data being panel data, time series and cross sectional. Therefore, fixed effects and random effects regression models were deployed. To select an appropriate model between random and fixed, the character of the individual effects is tested through Hausman's test.

To find out whether the Global Financial Crisis had any ameliorating effect on NPAs, a dummy variable (GFCDUM) is introduced, which takes the value one from the year 2008 and zero for other years. To assess the impact of ownership on NPAs ownership dummies (OPBDUM for old private banks and NPBDUM for new private banks) are included in the NPA equation. We begin the discussion of our analysis with the estimation results of the following versions of equations

\section{1. $\mathrm{NNPA}=\mathrm{f}$ (PRIADV, ROA, CAR, GRADV, SIZE, OCR, GGNP, GFCDUM, OPBDUM, NPBDUM).}

It is used to assess the impact of ownership along with bank specific and macroeconomic variables on NPAs of the banks using fixed effects panel regression model 
2. $\mathrm{NNPA}=\mathrm{f}(\mathrm{PRIADV}, \mathrm{ROA}, \mathrm{CAR}, \mathrm{GRADV}, \mathrm{SIZE}, \mathrm{OCR}, \mathrm{GGNP}$, GFCDUM, OPBDUM, NPBDUM).

It is used to assess the impact of ownership along with bank specific and macroeconomic variables on NPAs of the banks using random effects panel regression model

\section{Results and Discussion}

\subsection{Descriptive statistics and correlation}

Summary statistics for the set of variables in this study is presented in the following table

Table 6. Summary Statistics of Explanatory Variables

\begin{tabular}{|l|l|l|l|l|l|}
\hline Variable & Observations & Mean & Std. Dev. & Min & Max \\
\hline NNPA & 492 & 2.607 & 2.897 & 0 & 18.37 \\
\hline PRADV & 492 & 34.199 & 6.937 & 4.22 & 56.69 \\
\hline ROA & 492 & 0.969 & 0.527 & -3.38 & 2.43 \\
\hline CAR & 492 & 13.203 & 3.91 & 0 & 56.41 \\
\hline GRADV & 451 & 25.708 & 32.737 & -80.94 & 568.92 \\
\hline SIZE (Ln Assets) & 492 & 14.978 & 1.449 & 10.97 & 18.71 \\
\hline OCR & 492 & 1.977 & 0.563 & 0.6 & 4.07 \\
\hline GGNP & 492 & 7.24 & 1.883 & 3.99 & 9.75 \\
\hline
\end{tabular}

Source: Author Computations

The volatility of variables lies within the expected range except for the variable of growth in advances (GRADV) which seems to be dominated by outliers. Furthermore, we note that average NPA ratio of $2.6 \%$ is on higher side when compared with global standards (Table 4). Mean profitability of $0.97 \%$ with volatility. $52 \%$ is moderately good and capital adequacy of $13.2 \%$ is higher than the stipulated ratio of $9 \%$ (RBI 2004). The following table indicates the matrix of correlation coefficients between NPA ratio and independent variables. It is evident that there is no problem of multi-collinearity (Mean VIF $=1.25)$ 
Table 7. Correlation Matrix of Explanatory Variables

\begin{tabular}{|l|l|l|l|l|l|l|l|l|}
\hline Variables & NNPA & PRADV & ROA & CAR & GRADV & SIZE & OCR & GGNP \\
\hline NNPA & 1 & & & & & & & \\
\hline & & & & & & & & \\
\hline PRADV & $-0.0913^{*}$ & 1 & & & & & & \\
\hline & 0.043 & & & & & & & \\
\hline ROA & $-0.3626^{*}$ & 0.082 & 1 & & & & & \\
\hline & 0 & 0.0693 & & & & & & \\
\hline CAR & $-0.2666^{*}$ & 0.0423 & 0.2906 & 1 & & & & \\
\hline & 0 & 0.3495 & 0 & & & & & \\
\hline GRADV & $-0.1216^{*}$ & -0.2158 & 0.0715 & 0.0264 & 1 & & & \\
\hline & 0.0097 & 0 & 0.1294 & 0.5767 & & & & \\
\hline SIZE & $-0.3409^{*}$ & -0.2797 & 0.0788 & -0.1426 & 0.1015 & 1 & & \\
\hline & 0 & 0 & 0.0806 & 0.0015 & 0.0311 & & & \\
\hline OCR & $0.4843^{*}$ & 0.203 & -0.3829 & -0.0895 & -0.1779 & -0.3973 & 1 & \\
\hline & 0 & 0 & 0 & 0.0473 & 0.0001 & 0 & & \\
\hline GGNP & $-0.5967^{*}$ & 0.2037 & 0.0706 & 0.0876 & 0.032 & 0.1908 & -0.2726 & 1 \\
\hline & 0 & 0 & 0.1176 & 0.0521 & 0.4978 & 0 & 0 & \\
\hline
\end{tabular}

Note: * Significant at $1 \%, * *$ Significant at 5\%

Source: Author Computations

Observing the summary results of model 1 (Table 8 ), it is found that the coefficients of the variables considered have mixed results. PRADV is negatively significantly associated with NPAs. This result is against the popular belief that incidence of NPAs is significantly due to directed lending captured by proportion of priority sector advances to total advances. Due to rationalization of sub components in directed lending and deregulation of interest rates, priority sector advances are disbursed on market principles and resulting in lower NPAs than expected. ROA is found to be negatively associated with NPAs indicating that highly profitable banks exhibit efficient credit management system and thus lowers NPAs. CAR is significantly negatively related to NPAs indicating that highly capitalized banks exhibit lower NPAs. Growth in Advances (GRADV) is negatively associated with NPAs indicating that banks which concentrate on more lending may have developed expertise in effectively managing credit risk and hence may exhibit lower NPAs. The coefficient of SIZE turns out to be negative indicating that smaller banks are vulnerable to high proportion of NPAs which is evident from the burgeoning NPAs of smaller banks in recent years. OCR is found to be positively associated with NPAs. In other words, inefficient banks have higher incidence of NPAs. Coming to macroeconomic conditions, it is found that GNP growth is significantly negatively associated with NPAs, which would signify that the bad loans problem is less when the economy at large is doing well and the macro-economic environment is conducive for business growth. 


\subsection{Impact of Ownership}

To estimate the impact of ownership of banks on NPAs, ownership dummies (OPBDUM for old private banks and NPBDUM for new private banks) are included in Model 1 and 2. The results indicate that new private banks and old private banks are different from public sector banks in management of NPAs. Management of NPAs is better with new private banks than old private banks.

\subsection{Impact of the Global Financial Crisis}

To understand the impact of global financial crisis a dummy variable (GFCDUM) is introduced in model 1 and 2. The global financial crisis has indeed hampered the credit activity in Indian Banking sector as corporates cut down their expansion plans due to recessionary conditions. It was expected that incidence of NPAs would have increased after global financial crisis. Surprisingly, GFCDUM is significantly negatively related to NPAs in random effects model and negatively related in fixed effects model. The cautious credit policy of the banks and meticulous supervision of RBI to cut down the high levels of NPAs during global financial crisis could be the reasons for the significant decline in NPAs after 2008. 


\section{Macrothink}

Asian Journal of Finance \& Accounting

ISSN 1946-052X

2015, Vol. 7, No. 1

Table 8. Empirical Results of Impact of Macro Economic and Banking Variables (2001-2012)

\begin{tabular}{|c|c|c|c|c|}
\hline \multirow[t]{2}{*}{ Variables } & \multicolumn{2}{|c|}{ Model 1 (FE) } & \multicolumn{2}{|c|}{ Model 2(RE) } \\
\hline & $\mathrm{B}$ & t.s & $\mathrm{B}$ & t.s \\
\hline (Constant) & 30.29569 & 8.39 & 17.72678 & 7.67 \\
\hline PRIADV & -.0296805 & -1.49 & -.0492046 & $-2.97 *$ \\
\hline ROA & -.7456199 & $-4.01 *$ & -.7529061 & $-4.25^{*}$ \\
\hline CAR & -.0805 & $-3.10 *$ & -.0807964 & $-3.40 *$ \\
\hline GRADV & -.0033494 & -1.39 & -.0053859 & $-2.28 *$ \\
\hline SIZE & -1.449958 & $-5.95^{*}$ & -.5274061 & $-3.91 *$ \\
\hline OCR & .4623289 & $1.83 * *$ & .5871993 & $2.63 *$ \\
\hline GGNP & -.544519 & $-11.19^{*}$ & -.5714354 & $-11.97 *$ \\
\hline GFCDUM & -.2657603 & -0.94 & -1.136536 & $-5.53 *$ \\
\hline OPBDUM & 0 & (omitted) & -.5565324 & -1.35 \\
\hline NPBDUM & 0 & (omitted) & -.7113089 & -1.51 \\
\hline $\mathbf{R 2}$ & \multicolumn{2}{|l|}{0.3544} & \multicolumn{2}{|l|}{0.5486} \\
\hline between $=$ & \multicolumn{2}{|l|}{0.1546} & \multicolumn{2}{|l|}{0.3627} \\
\hline Within $=$ & \multicolumn{2}{|l|}{0.6055} & \multicolumn{2}{|l|}{0.5905} \\
\hline $\mathbf{N}$ & \multicolumn{2}{|l|}{451} & \multicolumn{2}{|l|}{451} \\
\hline $\mathrm{F}(10,400)$ & \multicolumn{2}{|l|}{$77.11 *$} & \multicolumn{2}{|l|}{ 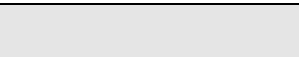 } \\
\hline Prob $>$ F & \multicolumn{2}{|l|}{0.0000} & \\
\hline Number of groups & \multicolumn{2}{|l|}{41} & \multicolumn{2}{|l|}{41} \\
\hline Wald chi2(10) & & & \multicolumn{2}{|l|}{$596.70^{*}$} \\
\hline Prob $>$ chi2 & & & \multicolumn{2}{|l|}{0.0000} \\
\hline (a) Hausman Test & \multicolumn{3}{|c|}{$\operatorname{chi} 2(8)=28.42 *$} & Prob $>$ chi $2=\quad 0.0004$ \\
\hline Mean VIF & \multicolumn{4}{|l|}{$1.25^{\wedge}$} \\
\hline
\end{tabular}

Note: * Significant at $1 \%$, ** Significant at $10 \%$

$\wedge$ VIF less than 10 indicates that there is no multi collinearity problem among explanatory variables \# F-test is statistically significant, which means that the FE model is statistically significant \$ Wald test is statistically significant, which means that the RE model is statistically significant (a) Hausman Test is statistically significant and rejects the null hypothesis of "Ho: difference in Coefficients not systematic"

Source: Authors 
Table 8A. Expected and Observed Signs of Independent Variables with Dependent Variable

\begin{tabular}{|l|l|l|l|}
\hline Variables & NNPA & \multicolumn{2}{|l|}{ Statistically Significant estimated signs } \\
\hline & & Fixed Effects & Random Effects \\
\hline PRIADV & + & & - \\
\hline ROA & - & - & - \\
\hline CAR & - & - & - \\
\hline GRADV & - & & - \\
\hline SIZE & - & - & - \\
\hline OCR & + & + & + \\
\hline GGNP & - & - & - \\
\hline GFCDUM & + & & - \\
\hline OPBDUM & - & & \\
\hline NPBDUM & - & & \\
\hline
\end{tabular}

Source: Authors

\section{Conclusion and Policy Implications}

This paper reviews the problem of NPAs in Indian Banking. The magnitude of the problem, the associated prudential norms, and different policy responses undertaken to address it were discussed. An empirical analysis was undertaken to identify the determinants of NPAs in Indian banking. Finally, the impact of ownership and global financial crisis on NPAs were investigated. For the purpose of the empirical analysis panel data of 41 Indian banks (which covers $88 \%$ of Indian banking assets) for twelve years from 2001 to 2012 was considered.

First, the impact of priority sector lending on NPA levels is negative and significant, indicating that NPA problem in India is more due to lending to non priority sectors and sensitive sectors such as personal loans and real estate loans. Second, larger banks exhibit better credit risk management demonstrated by lower NPAs as evident from the coefficient of SIZE (total assets) being negative and significant. Third, adequately capitalized bank also appear to have lower NPAs as evident from the coefficient of CAR being negative and significant. Fourth, the impact of growth in gross national product (GRGNP) on NPA levels is negative and significant indicating that favorable macroeconomic conditions help to lower NPA levels. Fifth, nature of ownership has a significant impact on NPA levels. Specifically, new private banks have the lowest NPA levels, followed by old private banks, and public sector banks in this order. Finally, policy measures initiated to tackle global financial crisis have been largely successful in achieving their objective of curtailing high NPA levels.

To tackle the problem of NPAs in Indian Banking system the RBI should focus on smaller banks and less profitable banks that seem to exhibit higher NPAs. Adequate attention should also be paid to banks with low operating efficiency and low capitalization as also to macroeconomic cycles that appear to be important in determining NPA levels. Finally, after accounting for all the above explanations for NPAs, it appears that the public sector, and to some extent the old private sector, accounts for the bulk of the NPA problem. Thus, while the policies that have been implemented to address the NPA problem may have been largely 
successful, there are further steps that can be taken by the RBI as well as by the banks themselves to tackle the problem of NPAs. These relate to smaller banks, unprofitable banks, inefficient banks, especially during adverse macroeconomic conditions, and more so for the public and old private sector banks. These findings are of crucial importance to banks in order to improve their credit risk management and for the regulatory-supervisory authority in devising its policies, especially in view of the importance that is now being attached to the concept of risk-based supervision in order to prioritize the allocation of resources.

\section{References}

Baltagi B.H. (1995). Econometric analysis of panel data. New York: John Wiley \& Sons.

Berger, A.N., \& G., Udell. (2004). The Institutional Memory hypothesis and the procyclicality of bank lending behavior. Journal of Financial Intermediation, 13(4), 458-495. http://dx.doi.org/10.1016/j.jfi.2004.06.006

Bloem, A.M., \& Goerter, C.N (2001), The Macroeconomic Statistical Treatment of Non-Performing loans', Discussion Paper, Statistics Department of the IMF, December

Caprio, G., I.Atiyas, \& J.A.Hanson. (1994). Financial reform: theory and experience, Cambridge: Cambridge University Press

CDR Performance Report. (2014). available at http://www.cdrindia.org/statistical.htm

Chaudhury \& Sensarma. (2006). Non-Performing Assets in Indian Banking: Magnitude, Determinants and Impact of Recent Policy Initiative. India Development Report.

Clair, R.T. (1992). Loan Growth and Loan Quality: Some Preliminary Evidence from Texas Banks, Economic Review, Federal Reserve Bank of Dallas, Third Quarter, pp. 9-21

Colin, A.C., \& Trivedi P.K. (2005). Microeconometrics methods and applications. Cambridge: Cambridge university Press.

Das A., \& Ghosh S. (2007). Determinants of Credit Risk in Indian State owned Banks: An Empirical Investigation, MPRA Paper No. 17301, posted 16. September 2009 14:09 UTC, Online at http://mpra.ub.uni-muenchen.de/17301/

Espinoza, R. A., Williams, M. O., \& Prasad, A. (2010). Regional financial integration in the GCC (No. 10-90). International Monetary Fund. http://dx.doi.org/10.5089/9781451982589.001

Fernandez de Lis, Jorge Martínez Pagés, \& Jesús Saurina. (2000). Credit Growth, Problem Loans and Credit Risk Provisioning in Spain, Working paper No. 0018, Banco de Espana

Gabriel, J., V. Salas, \& J., Saurina. (2006). Determinants of Collateral. Journal of Financial Economics, 81(2). 255-281. http://dx.doi.org/10.1016/j.jfineco.2005.06.003

Greene, W. H. (2003). Econometric analysis. Pearson Education India.

Hsiao, C. (1985). Benefits and limitations of panel data, Econometrics Reviews, 4(1), 121-174. http://dx.doi.org/10.1080/07474938508800078 
Hsiao, C. (2014). Analysis of panel data (Vol. 54). Cambridge university press. http://dx.doi.org/10.1017/cbo9781139839327

HU, J. L., Li, Y., \& CHIU, Y. H. (2004). Ownership and nonperforming loans: Evidence from Taiwan's banks. The Developing Economies, 42(3), 405-420.http://dx.doi.org/10.1111/j.1746-1049.2004.tb00945.x

IMF, S., \& Soundness, R. F. (2013). Global financial stability report. International Monetary Fund.

India Committee on the Financial System, \& Narasimham, M. (1991). Report of the Committee on the Financial System. Reserve Bank of India, Department of Banking Operations and Development.

Jimenez, G., \& J.Saurina. (2006). Credit cycles, credit risk and prudential regulation, International Journal of Central Banking, 2, 65-98.

Kwan, S., \& R. Eisenbis. (1997). Bank Risk, capitalisation and operating efficiency, Journal of Financial Services Research, 12, 117-131. http://dx.doi.org/10.1023/A:1007970618648

Lyoha, \& Udegbunam. (1999). Prediction of Bank Failure Nigeria Using Financial Ratios and Logit Regression Model, Prajnan, pp 291-304

McGoven, J. (1993). Why Bad Loans happen to Good Banks, The Journal of Commercial Lending, Philadelphia, February, 78.

Mohan, Rakesh. (2003). Transforming Indian Banking: In Search of a Better Tomorrow, Reserve Bank of India Bulletin, January.

Mukherjee Paramita. (2003). Dealing With NPAs-Lessons from International Experiences, ICRA Bulletin- Money and Finance, 2(12), 64-90

Muniappan, G. (2002). The NPA Overhang Magnitude, Solution and Legal Reforms, Reserve Bank of India Bulletin, May

Namboodari TCG. (2001). NPA Prevention is Better Than Cure. Vinimaya, Oct-Dec, pp19-23

Narasimham, M. (1998). Report of the committee on banking sector reforms. Ministry of Finance, New Delhi.

Rajaraman, I., Bhaumik, S., \& Bhatia, N. (1999). NPA variations across Indian commercial banks: Some findings. Economic and Political Weekly, 161-168.

Rajaraman. I., \& Vashistha. G (2002), Non-Performing Loans of Indian Public Sector Banks-Some Panel Results, Economic \& Political Weekly, February

Ranjan and Dhal(2003), Non-Performing Loans and terms of credit of public sector banks in India:an empirical assessment, RBI occasional papers, Vol. 24, No 3 
Rao, Katuri Nageshwara (2000), NPAs Ground Realities, Chartered Financial Analyst, 5(8), 43.

Reddy, Y. V. (2004). Credit policy, systems and culture. Reserve Bank of India Bulletin, 58(3), 303-311.

Reserve Bank of India. (2013). Report on Banking Statistical Returns, Mumbai

Reserve Bank of India. (2013). Report on Trends and Progress of Banking in India , Mumbai

Salas, V., \& J., Saurina. (2002). Credit Risk in Two Institutional Regimes: Spanish Commercial and Savings Banks. Journal of Financial Services Research, 22, 203-224. http://dx.doi.org/10.1023/A:1019781109676

Shaker F. (2003). Reduction of NPAs- Key to Banking Reforms, Yojana, October

Shinde S.R., \& Kaveri V.S. (1992). Management of Non Performing Assets, Journal of Indian Institute of Bankers, April-June

Sood A. (2001). Non Performing Assets in Public Sector Banks- Analysis of Causes and Solutions Thereof, Indian Banks Association Bulletin, July, pp16-21

Stavros H. Arvanitis, Irakleia S. Tzigkounaki, Theodoros V. Stamatopoulos, \& Eleftherios I. Thalassinos. (2011). Dynamic Approach of Capital Structure of European Shipping Companies. International Journal of Economic Sciences and Applied Research, 5(3), 33-63

Thiagarajan, Somanadevi, Ayyappan, S., \& Ramachandran, A. (2011). Credit Risk Determinants of Public and Private Sector Banks in India, European Journal of Economics, Finance \& Administrative Sciences, 34, 147

Wooldridge, J.M. (2006). Introduction to econometrics, $B$, Athens: Edition Papazisi

World Bank Group (Ed.). (2014). World development indicators 2014. World Bank Publications. at:http://data.worldbank.org/indicator/FB.AST.NPER.ZS?order=wbapi_data_value_2013\%20 wbapi_data_value\%20wbapi_data_value-last\&sort=asc

\section{Appendix 1}

\section{Concept of Non Performing Assets}

The concept of NPAs dates back to the banking sector reforms. The term non- performing asset was coined by the Narasimham committee - I in 1991. It classified NPAs into three categories viz. A. Substandard assets. B. Doubtful assets and C. Loss Assets, based on the time period of default. In 1995, according to RBI, if the interest / installment of the principal has remained 'past due' for a specific period of time, it is called a NPA. Non- performing asset is one where interest or repayment of installment has not been made within sevenying default has been revised from time to time, in order to align the Indian accounting standards to the international standards. The changes in the time period for recognizing NPAs have been shown in the table 1 . 
Table 1. Changing Past due Period for Determining NPAs

\begin{tabular}{|l|l|}
\hline Year & Specific period \\
\hline 1994 & 3 quarters i.e. 270 days (past due) \\
\hline 1995 & 2 quarters i.e. 180 days (past due) \\
\hline 2000 & 1 quarters i.e. 90 days (past due) \\
\hline 2004 & 1 quarters i.e. 90 days (without past due) \\
\hline
\end{tabular}

Source: Compilation by authors

Thus, from the norm of classifying only those assets as non performing which are four quarters past due and which was applicable until 1993, RBI moved to the norm of three quarters past due in 1994 and then to two quarters (180 days) past due in 1995. In 2001, RBI reduced this further by removing the past due concept. The 90 days norm comes into force with effect from March 31, 2004. According to Securtisation and Reconstruction of Financial Assets and Enforcement of Security Interest Ordinance, 2002, Non Performing Asset means "an asset or account of a borrower which has been classified by a bank or financial institution as substandard, doubtful or loss asset". Thus, the definition of NPAs was clearly spelt out in 1993. But the time period has been gradually revised from time to time, starting from 360 days default to 90 days deadline by the year 2004. Assets that generate income for the bank, that is, non NPAs, are known as standard assets. Once an asset becomes an NPA, banks have to make provision for the uncollected income from these assets. The provisioning is made on the basis of the classification of assets i.e. sub-standard, doubtful, and loss assets.

\section{Provisioning norms}

1) Loss assets should be either written off or 100 per cent of the outstanding should be provided for. 2) In case of doubtful assets, provisioning requirement is 100 per cent of the 'unsecured portion' and for the 'secured portion' the requirement ranges from 20 per cent to 100 per cent depending on the age of the NPA. 3) In the case of sub-standard assets, provision of 15 per cent on total out-standing is to be made. Sub-standard assets which are also 'unsecured exposures' require additional provisioning of 10 per cent, that is, a total of 25 per cent on the outstanding balance. In the case of standard assets, banks are required to make a general provision of a minimum of 0.4 per cent.

1 The Hausman specification test compares the fixed versus random effects under the null hypothesis that the individual effects are uncorrelated with the other regressors in the model (Hausman 1978). If correlated (H0 is rejected), a random effect model produces biased estimators, violating one of the Gauss-Markov assumptions; 
so a fixed effect model is preferred. Hausman's essential result is that the covariance of an efficient estimator with its difference from an inefficient estimator is zero (Greene 2003). 